\title{
DERMATITIS ATOPIK PADA ANAK
}

\author{
Nurelly N. Waspodo*, Junia Kirana**, Farida Tabri**, Faridha. S. Ilyas** \\ *Fakultas Kedokteran Universitas Muslim Indonesia \\ ${ }^{* *}$ Fakultas Kedokteran Universitas Hasanuddin
}

\begin{abstract}
Abstrak
Dermatitis atopik adalah penyakit kulit kronik relaps yang terjadi umumnya pada anak tapi dapat juga terjadi pada orang dewasa. Rash ditandai dengan papul yang gatal (umumnya vesikel pada infant) yang menjadi ekskoriasi dan likenifikasi, dan khas terdapat pada daerah fleksural. Etiologi dan patogenesis penyakit ini merupakan kompleks interaksi antara suseptibilitas genetik yang menghasilkan defek barier kulit, defek pada sistem innate immunity, dan meningkatkan respon imunologik alergen dan antigen mikroba.

Dilaporkan satu kasus dermatitis atopik, yang memberikan respon baik terhadap pengobatan dengan kortikosteroid topikal dan antihistamin.
\end{abstract}

Kata kunci: Dermatitis Atopik, Kortikosteroid

\section{PENDAHULUAN}

Dermatitis atopik adalah penyakit kulit kronik relaps yang terjadi umumnya pada anak-anak tapi dapat juga terjadi pada orang dewasa. Dermatitis atopik dibagi menjadi tiga tahap: dermatitis atopik infantil, yang terjadipadabayibarulahirsampaiduatahun; dermatitis atopik pada anak, usia 2 tahun sampai 11 tahun; dan dermatitis atopik pada orang dewasa. ${ }^{[1-3]}$

Etiologi dan patogenesis penyakit ini merupakan kompleks interaksi antara suseptibilitas genetik yang menghasilkan defek barier kulit, defek pada sistem innate immunity, dan meningkatkan respon imunologik alergen dan antigen mikroba. Terdapat komponen genetik yang kuat, tapi faktor lingkungan juga berperan. ${ }^{[1,6,7]}$
Prevalensi penyakit atopik seperti dermatitis atopik dan asma lebih meningkat pada dekade terakhir, dan menjadikan alergi menjadi masalah yang serius. Berbagai faktor bisa mencetuskan dermatitis atopik termasuk makanan, alergen musiman, kondisi lingkungan, bahan iritan, stres emosional dan paparan akibat pekerjaan. ${ }^{[8-11]}$

Dermatitis atopik sering terkait dengan asma yang kejadiannya lebih tinggi pada anak-anak dibandingkan dengan dewasa dan secara signifikan tergantung pada lingkungan sekitar dan terkait dengan alergi. ${ }^{[1,2]}$

\section{LAPORAN KASUS}

Seorang anak perempuan, usia 9 tahun datang dengan keluhan gatal pada kedua siku tangan, lipat tangan, kedua lutut, lipat lutut serta bokong sejak \pm 2 minggu yang lalu, gatal 
yang dirasa disertai dengan kulit menjadi kering, dan berwarna kehitaman, dimana awalnya \pm 1 bulan yang lalu rasa gatal yang timbul dirasakan pada kedua siku tangan, semakin lama rasa gatal dirasakan pada area kedua lipat tangan, kedua lutut, lipat kaki, serta bokong, sehingga pasien selalu menggaruk dan menimbulkan warna kemerahan sampai menjadi kehitaman.

Ibu pasien mengatakan pasien sering mengalami keluhan yang sama seperti ini sejak \pm usia 5 bulan, namun semakin memberat sekitar 1 tahun ini, gatal dan kemerahan di kulithilang timbul, biasanya muncul keluhan setelah pasien berkeringat, mengkonsumsi ayam potong, telur dan makanan ringan.

Riwayat penyakit asma pada keluarga diakui ibu pasien (ibu pasien dan keluarga pasien), riwayat keluarga sakit yang sama diakui (pada kakak kandung pasien), riwayat pengobatan sebelumnya diakui ibu pasien, pasien pernah berobat ke dr spesialis kulit dan diberi obat minum (lupa nama obat), dan obat salep (salep hidrokortison) yang dioles dua kali sehari, ibu pasien mengatakan sempat membaik, tidakgatal.Ibu pasien mengatakan pasien sering menggaruk kulitnya jika gatal sampai menimbulkan luka.

Pada pemeriksaan fisik keadaan umum pasien tampak sakit ringan, gizi tampak kesan cukup, berat badan $20 \mathrm{~kg}$, kesadaran kompos mentis, nadi 80x/menit, pernafasan 20x/ menit, suhu $36^{\circ}$. Status dermatologis pada regio fossa antekubiti bilateral, olecranon bilateral, patella, dan poplitea terdapat effloresensi papul papul hiperpigmentasi, ekskoriasi, xerosis (Gbr. 1-4)

Pada pasien telah dilakukan pemeriksaan prick test, dan didapat hasil negatif, dan rencana akan dilakukan pemeriksaan IgE serum total dan TEWL, namun orang tua pasien menolak, pada pasien dilakukan penilaian berdasarkan kriteria Hanifin dan Rajka, dan didapat pada pasien tiga kriteria mayor berupa pruritus, morfologi dan distribusi khas (keterlibatan fasial dan ekstensor pada bayi dan anakanak), kecenderungan terhadap dermatitis kronis atau kronis kambuhan, dan riwayat atopik pada diri sendiri atau keluarga (asma, rinitis alergi, dermatitis atopik), kriteria minor berupa xerosis, gatal saat berkeringat, dan intoleransi makanan.

Berdasarkan anamnesis, pemeriksaan fisik, dan pasien memenuhi kriteria Hannifin dan Rajka sehingga didiagnosis akhir dengan Dermatitis Atopik, pada pasien ini diberikan sirup cetirizine $5 \mathrm{mg} / \mathrm{ml} \mathrm{2x1(jika} \mathrm{gatal),}$ mometason furoat cream 0 , 01\% dioleskan dua kali sehari, dan emolien. 


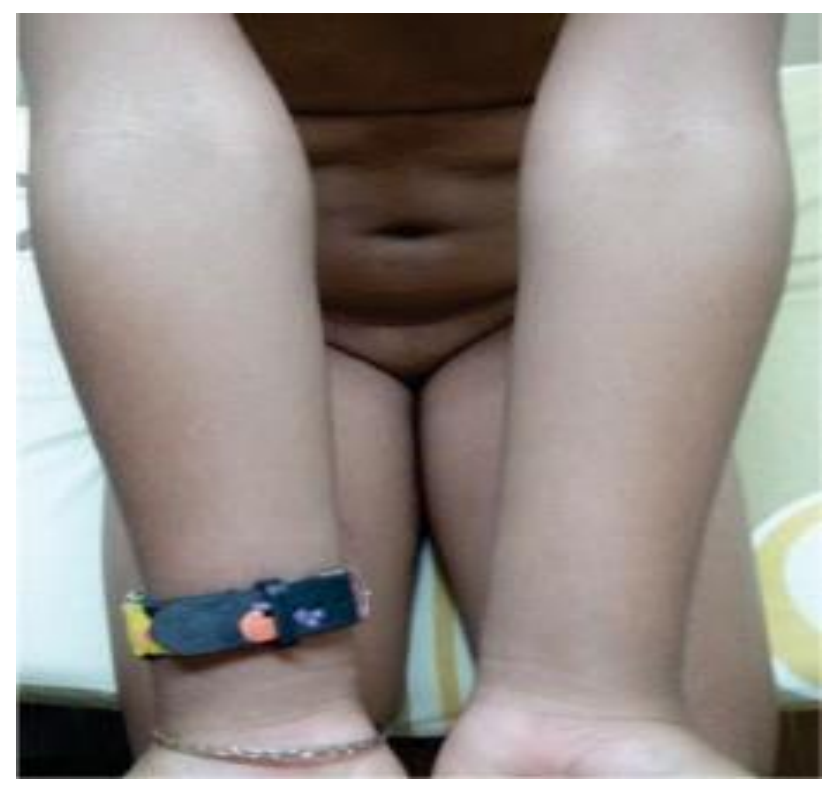

Gambar 1. Tampakekskoriasi, xerosis pada regio antekubiti bilateral

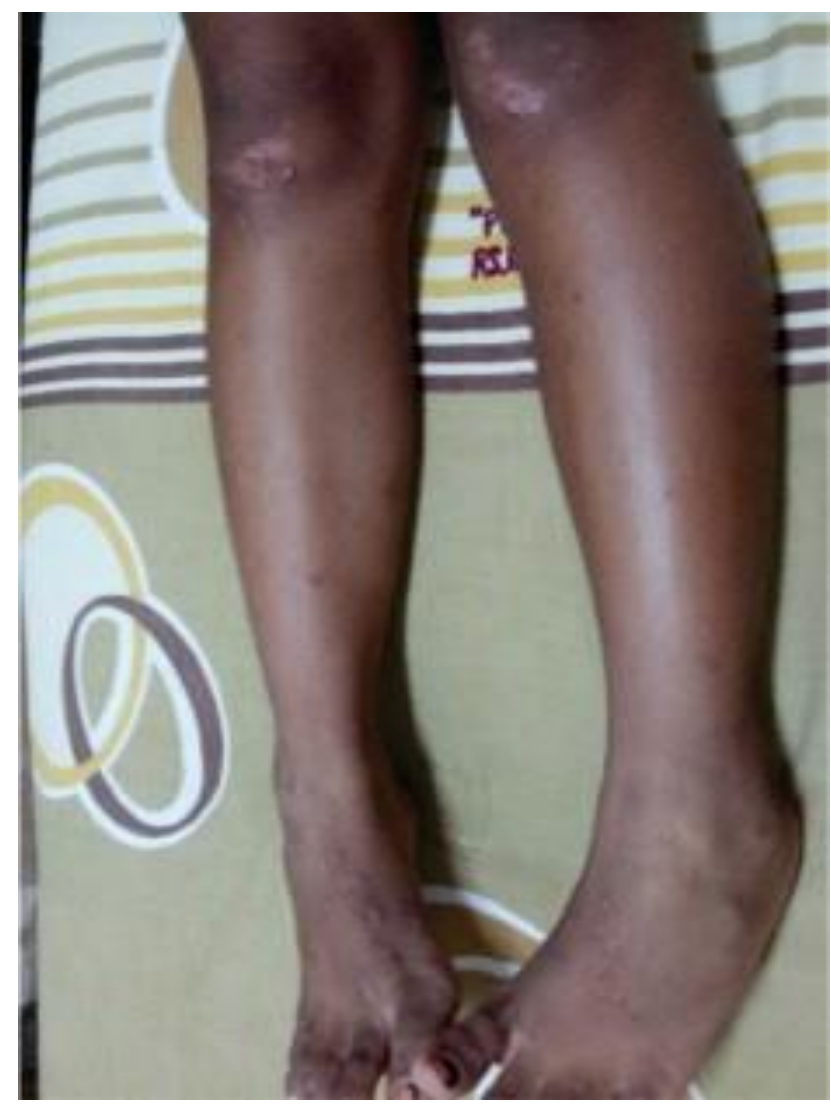

Gambar 3. Tampak papul-papul hiperpigmentasi, xerosis, ekskoriasi, pada regio patella bilateral

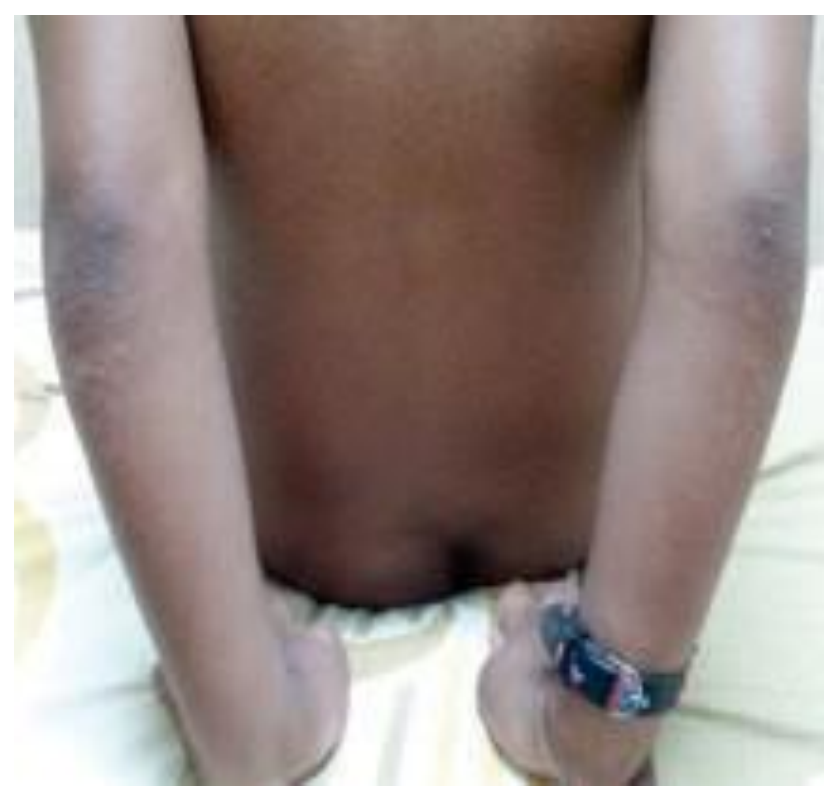

Gambar 2. Tampak papul-papul hiperpigmentasi, xerosis, ekskoriasi pada regio olecranon bilateral

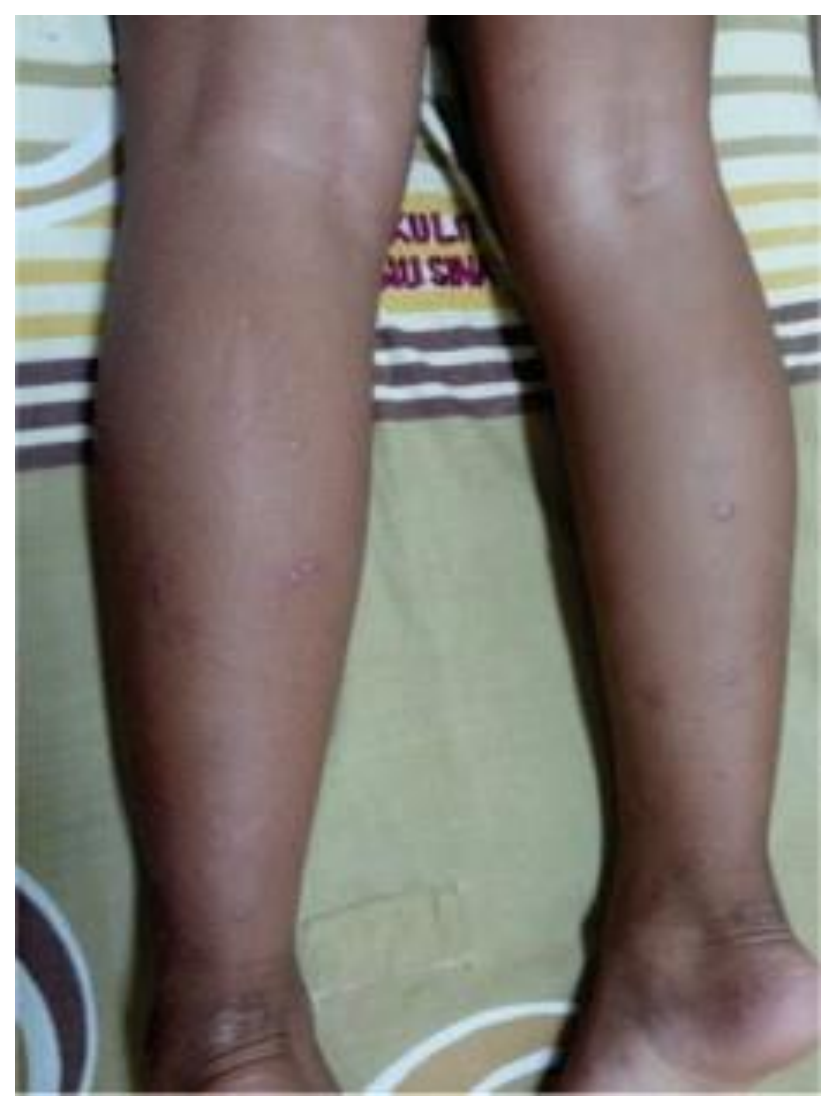

Gambar 4.Tampakxerosis, ekskoriasi, padaregio poplitea bilateral 
Pada kontrol pertama hari kedelapan, tampak lesi baru pada kulit. Status dermatologispada regiocollidekstra,tampak effloresensi plak likenifikasi, papul-papul hiperpigmentasi (gambar 5), regio patella bilateral, tampak effloresensi papul-papul hiperpigmentasi, pustul, xerosis, krusta (gambar 7), pada regio poplitea bilateral, tampak effloresensi plak likenifikasi, papul hiperpigmentasi, pustul, xerosis, dan krusta, pada regio gluteus, tampak effloresensi papul-papul hiperpigmentasi, pustul, dan xerosis (gambar 6.). Pengobatan pada pasien diberikan kompres nacl 0 , 9\% satu hari dua kali kompres selama 5-10 menit, sirup cefadroxil $125 \mathrm{mg} / 5 \mathrm{ml}$ 3x1, sirup cetirizine $5 \mathrm{mg} / \mathrm{ml} 2 \times 1$ (jika gatal), mupirocin ointment $5 \mathrm{gr}$ dioles dua kali sehari (dioles pada daerah pustul), mometason furoat $0,01 \% \mathrm{cream}$, serta emolien dioles pada tubuh yang kering.

\section{Foto kontrol pertama}

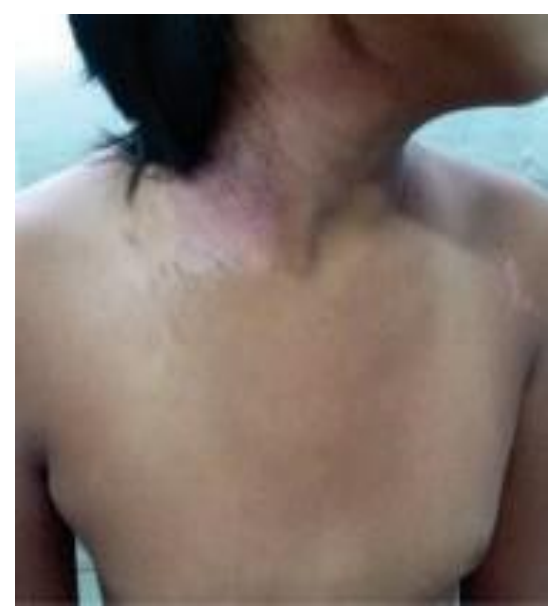

Gambar 5. Tampak plak likenifikasi, papul-papul hiperpigmentasi, pustul, krusta, xerosis, dan ekskoriasi pada regio colli dekstra

\section{Foto kontrol kedua}

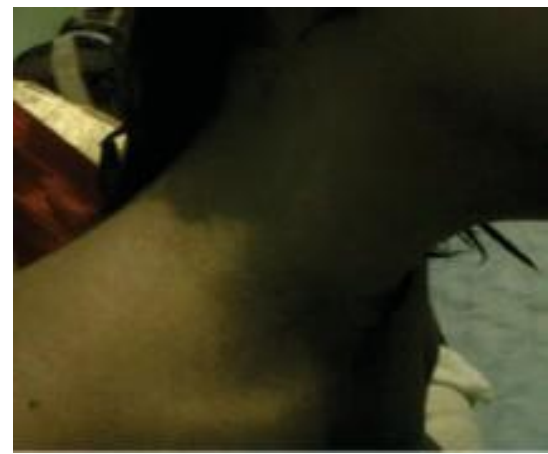

Gambar 8. Sudah tidak tampak lesi pada regio colli dekstra

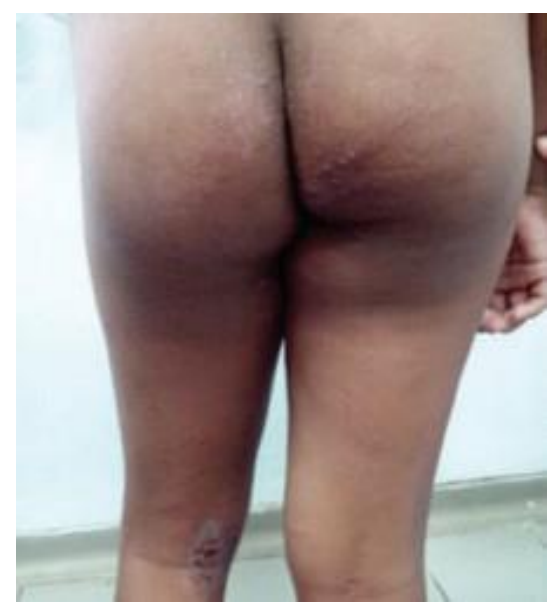

Gambar 6. Tampak plak likenifikasi, papul-papul hiperpigmentasi, pustul, krusta, xerosis, dan ekskoriasi pada regio gluteus dan poplitea bilateral

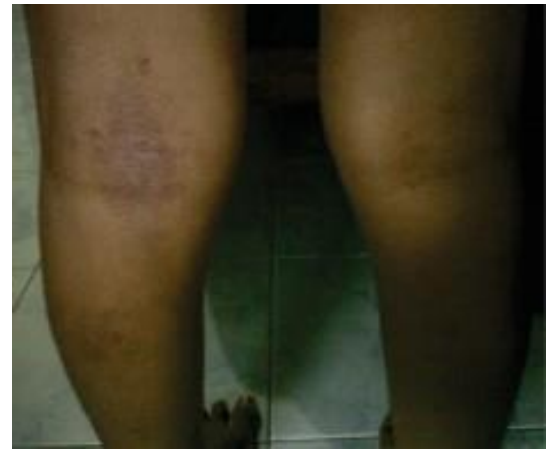

Gambar 9. Tampak plak likenifikasi menipis, dan tidak ada pustul pada regio poplitea bilateral

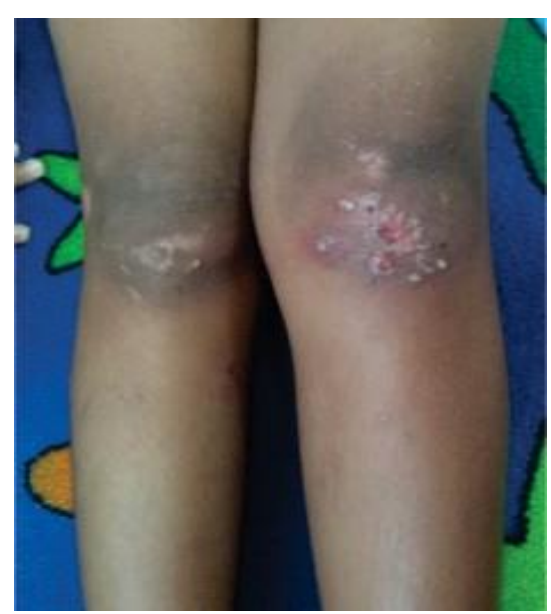

Gambar 7. Tampak papul hierpigmentasi, pustul, krusta, xerosispadaregiopatellabilateral

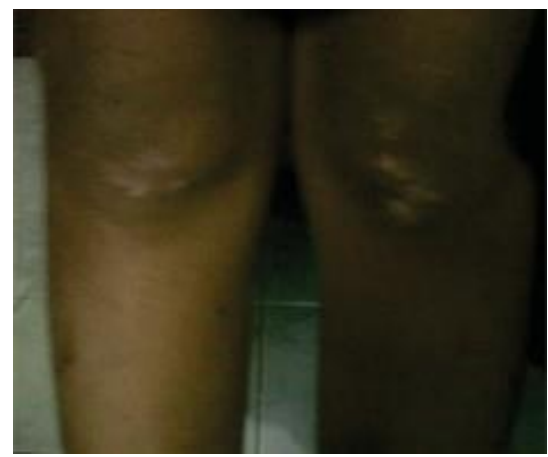

Gambar10.Sudahtidaktampak lesi pada regio patella bilateral 
Pada kontrol kedua kelimabelas, sudah tidak ditemukan lesi, Status dermatologis pada regio colli dekstra, patella, dan poplitea sudah tidak ditemukan pustul, likenifikasi menipis, dan keluhan gatal berkurang (gambar 8, 9, dan 10), Pengobatan pada pasien sirup cefadroxil $125 \mathrm{mg} / 5 \mathrm{ml}$ dihentikan, sirup cetirizine $5 \mathrm{mg} / \mathrm{ml}$ diberikan jika gatal, salep mupirocin ointment 5 gr dihentikan dan mometasone furoat $0,01 \%$ cream dan emolien tetap diberikan.

\section{PEMBAHASAN}

Pada kasus ini diagnosis dermatitiss atopik ditegakkan berdasarkan anamnesis, pemeriksaan fisik, dan berdasarkan kriteria Hanifin dan Rajka.

Dermatitis atopik pada kasus ini terjadi pada anak perempuan berusia 9 tahun, menurut kepustakaan dermatitis atopik adalah penyakit eksimatosa pruritik kronik yang hampir selalu bermula di masa kanakkanak dan mengikuti perjalanan sembuh atau kambuh yang berlanjut sepanjang hidup. ${ }^{[1,4]}$

Pada anamnesis didapat adanya keluhan gatal pada kedua siku tangan, lipat tangan, kedua lutut, lipat belakang kaki, serta bokong sejak \pm 2 minggu yang lalu SMRS. Gatal yang dirasa disertai dengan kulit menjadi kering dan berwarna kehitaman, awalnya \pm 1 bulan yang lalu rasa gatal yang timbul dirasakan pada kedua siku tangan, semakin lama rasa gatal dirasakan pada area kedua lipat tangan, kedualutut, lipat kaki belakang, serta bokong, sehingga pasien selalu menggaruk dan menimbulkan warna kemerahan sampai menjadi kehitaman. Sesuai kepustakaan pada fase kanak-kanak, yaitu umur 2-12 tahun penampilan dermatitis atopik yang paling umum dan khas adalah inflamasi di daerah fleksural, lokasi predileksi, yaitu fossa antekubiti dan poplitea adalah yang paling umum terkena, dengan leher, fleksural pergelangan tangan, dan pergelangan kaki sertabokong dan lipatan paha,inimerupakan daerah-daerah yang terutama mudah berkeringat. ${ }^{[2,3,12]}$

Status dermatologis pada regio colli dekstra, fossa antekubiti bilateral, poplitea, dan gluteus terdapat effloresensi papul-papul hiperpigmentasi, ekskoriasi, xerosis, pada regio olecranon bilateral, patella bilateral terdapat effloresensi papul-papul, ekskoriasi, erosi, xerosis, plak-plak likenifikasi, serta krusta. Sesuai kepustakaan pada fase kanak-kanak, daerah fleksural adalah lokasi predileksi fossa antekubiti dan poplitea adalah yang paling umum terkena, dengan leher, fleksur pergelangan tangan dan pergelangan kaki, danbokong sertalipat pahajuga terlibat, lesi-lesinya adalah bercak-bercak bersisik, eritematosa, pruritik, seringkali dipenuhi eksudasi, krusta, dan ekskoriasi. ${ }^{[2,4]}$

Pada kasus terdapat riwayat penyakit asma yang diderita pada ibu pasien dan keluarga pasien, serta terdapat riwayat penyakit yang sama pada kakak kandung pasien. Sesuai kepustakaan pada tahun 1916, Cooke dan Van der meer mengenali bahwa alergi berlangsung dalam keluarga, sejumlah penelitian menegaskan hubungan yang kuat dari penyakit atopik orang tua dan saudara pada anak-anak penderita dermatitis atopik, sebuah penelitian prospektif telah menunjukkan bahwa dermatitis atopik dan asma diwarisan melalui jalur gen yang berbeda, sepertiga sampai dua pertiga pasien rawatinap dermatitis atopik memiliki riwayat orang tua tunggal atau ganda terhadap atopik 
dan ini bahkan lebih tinggi saat saudara kandung dilibatkan, asma alergik atau rinitis alergik pada orang tua adalah faktor minor dalampengembangan dermatitis atopikpada keturunannya, tujuh puluh persen pasien atopik memiliki riwayat keluarga dari satu atau lebih karakteristik atopik utama. ${ }^{[2-4,13,14]}$

Pada pasien ini dilakukan pemeriksaan prick test dan didapatkan hasil negatif, rencana pasien akan dilakukan pemeriksaan IgE serum total dan TEWL, namun orang tua pasien menolak. Menurut kepustakaan kadar IgE meningkat dalam serum dari sejumlah pasien penderita dermatitis atopik, tetapi $20 \%$ dari pasien dermatitis atopik memiliki kadar IgE serum normal dan tidak ada reaktifitas alergen, kadar IgE selalu berkolerasi dengan aktivitas penyakit, oleh karena itu meningkatnya kadar IgE serum hanya dapat dianggap mendukung bukti ke arah penyakit, IgE serum total jauh lebih tinggi pada anak-anak yang secara bersamaan menderita penyakit respiratorik atopik, sebagian besar penderita dermatitis atopik memiliki riwayat pribadi atau keluarga terhadaprinitis alergik atau asma dan antibodi IgE serum yang meningkat terhadap antigen protein udara atau ingesti. Disfungsi sawar epidermal ditandai dengan kulit kering dan bersisik (xerosis) yang mempengaruhi daerah berlesi dan tidak berlesi, dan menyebabkan meningkatnya kehilangan air transepidermal (TEWL) yang khas, kulit kering adalah gambaran penting dari keadaan atopik, kulit yang kering sensitif, mudah teriritasi oleh stimulus eksternal dan menimbulkan gatal, gatal inilah yang memberikan dasar bagi pengembangan berbagai pola dermatitis atopik, pruritus adalah gambaran yang konstan dan sebagian besar perubahan kulit dipicu oleh gatal, gatal bersifat paroksimal, garukan mengakibatkan likenifikasi dan dapat menyebabkan infeksi sekunder, pada pasien atopik, sawar epidermal abnormal, bahkan pada kulit yang tampaknya normal, peningkatan dalam TEWL berkolerasi dengan keparahan penyakit. ${ }^{[1,2,4,15]}$

Pada pasien ini dilakukan penilaian berdasarkan kriteria Hannifin dan Rajka, dan didapat pada pasien tiga kriteria mayor berupa pruritus, morfologi dan distribusi khas (keterlibatan fasial dan ekstensor pada bayi dan anak-anak), kecenderungan terhadap dermatitis kronis atau kronis kambuhan, dan riwayat atopik pada diri sendiri atau keluarga (asma, rinitis alergi, dermatitis atopik), kriteria minor berupa xerosis, gatal saat berkeringat, dan intoleransi makanan. Menurut kepustakaan pada tahun 1980, Hanifin dan Rajka untuk pertama kalinya menyusun kriteria standar untuk diagnosis dermatitis atopik, dimana pada pasien harus memiliki tiga kriteria mayor dan tiga kriteria minor. ${ }^{[1-4,16]}$

Menurutkepustakaantujuanpengobatan terdiri dari berupaya untuk menghilangkan inflamasi dan infeksi, mempertahankan dan mengembalikan pembatas stratum korneum dengan menggunakan emolien, penggunaan emolien efektif untuk meningkatkan hidrasi kulit, mengembalikan dan melindungi sawar stratum korneum yang dikombinasikan dengan terapi hidrasi, dan dapat mengurangi kebutuhan akan glukokortikoid topikal, terapi emolien dan hidrasi kulit merupakan terapi dermatitis atopik, menggunakan agen antipruritik untuk mengurangi kerusakan yang ditimbulkan oleh diri sendiri pada kulit yang terlibat, steroid topikal digunakan untuk menekan inflamasi pada dermatitis atopik, 
glukokortikosteroid topical merupakan terapi yang penting, selama beberapa tahun risiko dariefek samping karena penggunaan steroid topicaldapatditekan dengan mengoptimalkan aplikasi obat dan penggunaan preparat steroid yang baru dengan efek yang lebih baik dan efek samping yang lebih sedikit, seperti prednicarbate, mometasone furoat, fluticarsone, dan metholprednisolon aceponate, jika pengkrustaan atau pustulasi yang terlihat bersama infeksi maka antibiotik harus diberikan, antibiotik oral lebih efektif daripada antibiotik topikal untuk mengontrol infeksi. Pada pasien ini diterapi dengan sirup cefadroxil $125 \mathrm{mg} / 5 \mathrm{ml}$ sirup, sirup cetirizine $5 \mathrm{mg} / \mathrm{ml} 10 \mathrm{mg}$ 2x1 (bila gatal), mometasone furoat $\mathrm{o}, 01 \%$, dan mupirocin ointment $5 \mathrm{gr}{ }^{[1-}$ 4, 17-19]

\section{DAFTAR PUSTAKA}

1. Leung, D.Y.M., L. F. Eichenfield, and M. Boguniewicz, Atopic Dermatitis (Atopic Eczema), in Fitzpatrick's Dermatology in General Medicine, L. A. Goldsmith, et al., Editors. 2012, Mc Graw Hill: New York. p. 165-182.

2. Krafchik, B. R., Dermatitis Atopik, in Pediatry Dermatology, B. R. Krafchik, et al., Editors. 2010, Mosby Elsevier: USA. p. 851-878.

3. Atopic Dermatitis, Eczema, and Noninfectious Immunodeficiency Disorders, in Andrews' Diseases of The Skin Clinical Dermatology, W. D.James, T. G. Berger, and D. M. Elston, Editors. 2011, Elsevier Saunders: USA.p. 63-70.
4. Atopic Dermatitis, in Clinical Dermatology A Color Guide ToDiagnosis And Therapy, T.P.Habif, Editor 2010, Mosby Elsevier: USA. p. 154-180.

5. Trace Element Levels in Children with Atopic Dermtitis. J Investig Allergol clin Immunol, 2012. 22(5): p. 341-344.

6. Novak, N., New insights into the mechanismandmanagement of allergic diseases: atopic dermatitis Journal Compilation 2009. 64: p. 265-275.

7. Turner, J. D. and R. A. Schwartz, Atopic dermatitis A clinical challenge. Acta Dermatoven APA, 2009. 15(2): p. 59-68.

8. Bieber, T. and C. Bussmann, Atopic Dermatitis, in Dermatology, J. P.Callen, et al., Editors. 2012, Elsevier Saunders: USA. p. 203-217.

9. Buys, L. M. and P.D, Treatment Options for Atopic Dermatitis American Academy of Family Physicians, 2009. 75: p. 523528.

10. Campbell, D. E., Role of food allergy in childhood atopic dermatitis. Paediatrics and Child Health, 2011: p. 1058-1064.

11. Krakowski, A. C., L. F. Eichenfield, and M. A. Dohil, Management of Atopic Dermatitis in Pediatric Population. American Academy of Pediatrics, 2008: p. 812-824.

12. Thomas, J., Understanding Atopic dermatitis and its management in Children. e-Journal of the Indian Society of Teledermatology, 2009. 1: p. 1-11. 
13. Civelek, E., et al., Prevalence, Burden, and Risk Factor of Atopic Eczema in School Children Aged 10-11 Years: A National Multicenter Study. J. Investic Allergol Clin Immunol, 2011. 2(4): p. 270-277.

14. Fuiano, N. and C. Incorvaia, Dissecting the Causes of Atopic Dermatitis in Children: Less Foods, More Mites. Allergology International, 2012. 61(2): p. 231-243.

15. Lamberts, S. W.J., The Atopy Patch Test in the diagnostic work-up of pediatric patients with atopic dermatitis in Diagnostic Work-up and Treatment of Severe and/ Refractory Atopic Dermatitis S. W. J. Lamberts, Editor 2009, A. C. A Devillers: Netherlands. p.25-51.

16. Nicol, N. H., Efficacy and Safety Considerations in Topical Treatments for Atopic Dermatitis Pediatric Nursing, 2011. 37(6): p. 295-301.
17. Wahn, U., Diagnosis and treatment of atopic dermatitis in children and adults: European Academy of Allergology and Clinical Immunology / American Academy of Allergy, Asthma and Immunology / PRACTALL Consensus Report. The Journal of Allergy and Clinical Immunology and Allergy 2009: p. 969-987.

18. Chow, W. -C., Management of Atopic Eczema in Children. Medical Bulletin, 2009. 12(3): p. 13-15.

19. Mohammad, S., The Efficacy of Using Tacrolimus Ointment Children with Atopic Dermatitis. webmedcentral, 2012: p. 1-33. 
